\title{
"The Old Wild West in the New Middle East": American Sniper (2014) and the Global Frontiers of the Western Genre
}

Lennart Soberon

\section{OpenEdition}

\section{Journals}

Electronic version

URL: https://journals.openedition.org/ejas/12086

DOI: 10.4000/ejas.12086

ISSN: 1991-9336

Publisher

European Association for American Studies

Electronic reference

Lennart Soberon, "'The Old Wild West in the New Middle East": American Sniper (2014) and the Global

Frontiers of the Western Genre", European journal of American studies [Online], 12-2 | 2017, document

12, Online since 01 August 2017, connection on 08 July 2021. URL: http://journals.openedition.org/ ejas/12086 ; DOI: https://doi.org/10.4000/ejas.12086

This text was automatically generated on 8 July 2021 .

Creative Commons License 


\title{
"The Old Wild West in the New Middle East": American Sniper (2014) and the Global Frontiers of the Western Genre
}

\author{
Lennart Soberon
}

While recent years have seen no shortage of American action thrillers dealing with the War on Terror-Act of Valor (2012), Zero Dark Thirty (2012), and Lone Survivor (2013) to name just a few examples-no film has been met with such a great controversy as well as commercial success as American Sniper (2014). Directed by Clint Eastwood and based on the autobiography of the most lethal sniper in U.S. military history, American Sniper follows infamous Navy Seal Chris Kyle throughout his four tours of duty to Iraq. Since its December 2014 release the film has earned close to half a billion dollars worldwide and is considered to be the highest grossing war film of all time. Apart from this boxoffice bravura the film also received six Academy Award nominations, including for best picture, and was met with generally good reviews (at the time of writing, both the Rottentomatoes and Metacritic score lies at 72\%). At the background of this financial and critical success lies the problem of American Sniper's political agenda, which has generated a heated debate. Some newspapers and film magazines decried the movie as being little more than jingoist propaganda, glorifying a mass murderer. Rolling Stone called the movie "a two-hour cinematic diversion about a killing machine with a heart of gold who slowly, very slowly, starts to feel bad after shooting enough women and children" (Taibi). The controversy came to a boiling point when following the film's release a twitter storm of Islamophobic death threats prompted the American-Arab Anti-Discrimination Committee (ADC) to ask for police protection against retaliation from moviegoers (Woold). These voices, however, were only one side of the debate concerning the film's themes and political agenda. A large amount of journalists and reviewers perceived the film as a respectful treatment of a difficult theme and a triumphant comeback for Eastwood as a director after a series of lukewarm received film such as Jersey Boys (2014) and J. Edgar (2011). 
2 This article contributes to the debate through a critical analysis of how American Sniper transcodes a jingoist discourse of the Iraq War. American Sniper's creative team has repeatedly stressed in interviews that the film does not contain a political message. Despite the accusations that American Sniper is a semi-propaganda film, Eastwood has said that he considers both the film and himself to be anti-war (Dockterman). Screenwriter Jason Hall and main actor/producer Bradley Cooper also have stressed the politically neutral nature of the film, albeit using a different argument: "This movie was always a character study about what the plight is for a soldier.... It's not a political discussion about war" (Kain). Hall claims that the story is not about the war in Iraq, but about an individual-and this makes it strictly a-political. However, it's not uncommon for war films to focalize American conflict through the experiences of a single soldier, and neither is the perpetuation of certain discourses by means of such an individual perspective. This article argues that American Sniper has an obvious political agenda in advocating a view of the 2003 Iraq invasion-and the subsequent military measures taken in that context-as just and necessary. Such a framing of the conflict is achieved through certain mythological mechanisms.

3 As this article demonstrates, American Sniper frames its subject matter and themes partially through the conventions of the Western genre, tapping heavily into Western tropes, iconography and, most importantly, frontier mythology. In doing so American Sniper seemingly de-politicizes an inherently political subject. By employing the generic frame of the classical Western American Sniper transfigures a politically complex conflict into a moral, manicheist struggle between civilization and savagery. Through this process of mythic configuration, the film reinforces the US administration's dominant views of the Iraq War as a just and necessary execution in the light of 9/11. Applying insights from genre theory, conflict studies and narratology, this article focuses on the political power of genre and myth as interpretative frameworks through which the hegemonic discourse around the Iraq-invasion can be reaffirmed. The first part of the article historicizes the Western film, discussing its generic, ideological and mythic components as to better understand the rhetorical power embedded within the Western genre. The second part provides a textual analysis of the film in relation to these components. This analysis is primarily focused on uncovering the generic and mythic structures the film utilizes by looking at the binary oppositions around which the narrative revolves, as well as at how these oppositions manifest themselves through the film's representation of its hero and villain characters.

\section{The Western: Genre, Myth and Ideology}

\subsection{Once Upon a Time in the West}

4 The Western has an important place in both the history of narrative cinema as in the development of genre criticism as an academic field (Lusted 27-28). Spearheaded by André Bazin, who considered the genre to be "the American film par excellence" (Bazin 143), the Western became the subject of serious academic consideration by French film scholars in the 1950s (Lusted 18). Key to this academic appreciation was an interest in the genre's dialectic relationship with the American history. Despite centering on a relatively short period of time-the second cycle of the American 
frontier, or the fading out of the West-the countless narratives drawn from this historical period are considered to have had a profound influence on American culture. Needless to say, there is a substantial difference between the "historic" frontier and the "cinematic" one, but it was how the latter has transformed the perception of the former that has been a crucial subject of scholarly debate. Neil Campbell even considers the Western as a solidified type of origin story for the United States; one "materialized in the actions of its heroes and villains, and naturalized through its specific geomystical symbolic locations" (Post-Westerns 11). Novelists and filmmakers alike have found in the West an endless amount of rich material to weave stories from, thereby contributing to the evolution of American mythology (Carter).

A great deal of scholarship on the Western genre and its underlying mythology focuses primarily on debunking the myths of the Western by referring them to "real" history (Walker 8). Albeit an interesting subject of study, genre scholar Schatz sees the debate on the genre's historicity as irrelevant: the Western has little to do with history, its historical dimension has been surpassed by the mythical one. It is, however, the work of historian Richard Slotkin that has successfully redirected the debate by focusing on the ideological implications of Western myths. Not only is such a mediated rendering of history itself a discursive practice, but the mythic discourses can be considered "a constraining grammar of codified memories and beliefs" that is able to affect our outlook by engaging us into their oversimplified agendas (Levinson 9). As a mode of expression, myth offers its own kind of structured logic; its language is metaphorical and suggestive, rather than logical and analytical. Genre, myth and ideology are closely interlinked, according to Slotkin (Gunfighter Nation). Defining myth as a form of ideology expressed through narrative, he sees its power as stemming from its repeated uses across generations (Slotkin, Gunfighter Nation 6). What starts as stories drawn from a society's history, becomes, through retellings, an interpretive metaphor stabilizing that society's ideology. Over time, the original mythic story is "increasingly conventionalized and abstracted until it is reduced to a deeply encoded and resonant set of symbols, 'icons,' 'keywords,' or historical clichés" (Slotkin, Gunfighter Nation 5). The most striking quality of myths is that despite being products of human thought and mental labor, "their identification with venerable tradition makes them appear to be the products of "nature," rather than history-expressions of trans-historical consciousness or some form of natural law" (Slotkin, Gunfighter Nation 6). This definition complements Roland Barthes' fundamental notion of mythology, stating that "the very principle of myth [is that] it transforms history into nature" (129). Myths offer seemingly depoliticized narratives, while in fact the deliver an idealization of historical reality in which specific regimes of truth are affirmed.

It is the "imaginative" relationship to America's geography and history (Buscombe 16-17) that has made the Western such a fruitful topic of study. Buscombe refers to the genre's mythology as uniquely central to US history, culture and identity. This grand narrative has been conceptualized by many authors (Slotkin; King; Anderson; Carter) as the "frontier myth." slotkin has written extensively on the ideological workings of the frontier myth in his trilogy on the American West. Taking an anthropological approach to mythology, similar to Claude Lévi-Strauss's, he refers to the frontier narrative as grafted on oppositions: most notably that of civilization versus savagery, man versus nature, and good versus evil. These juxtapositions ask to be resolved by way of conflict, more precisely through the subordination of an unclaimed land-the frontier. To 
achieve this, the protagonist has to win a "savage war" against an inherent Other (the Indians), without venturing too much into the realm of that very savagery which he fights. Balancing between these oppositions the hero frontiersman turns out victorious, and claims the savage space as his own, which highlights the (American) values of selfreliance, democracy and freedom (Rose and Davis 29). Such a resolution, however, can only be achieved through a "temporary regression to a more primitive or 'natural' state"; through acts of regenerative violence that purge both the hero and his community (Slotkin, Regeneration).

7 Rose and Davis thus summarize the frontier myth: it "provides a theory of history in which conflict, violence and the subjugation of nature and original peoples are legitimized as natural and inevitable for ensuring the 'progress' of civilization" (29). It is therefore no wonder that Slotkin (Gunfighter Nation) sees great symbolic power in the frontier myth which has functioned as an effective metaphor in the justification of American expansionist efforts and military interventions. By way of frontier mythology, the Western has helped mold political ideals and provided politics with a well-known framework for the integration of ideas. This viewpoint is shared by Berg who notes that throughout the twentieth century, the Western "became key in the mythologizing process that helped rationalize central aspects of American domestic and foreign policy" (213). Key to this notion is the image of the cowboy-hero. Berg notes that the "Western" has a history with American political and economic imperialism, adding that "Westerns provided American with positive images keyed to the period's idealized profile of the American character" (213). That is: a rugged individual, at once courageous and caring. He is an inner-directed man of principle who, albeit at odds with the community, has the potential to save it. It is this sense of frontier heroism informs American Sniper.

8 As scholars such as Cawelti and Burgoyne have pointed out, the Western genre has proved to possess profound rhetorical power when it comes to sustaining and resisting certain discursive formations regarding violence, masculinity and nationhood within the American cultural landscape. During the Cold War era, for example, the Western often operated as metaphor through which one could read contemporary geopolitics. As Stephen Mexal argues, the Western offered the audiences of the time a mythic take on American history in which the West was won through a righteous struggle on behalf of the forces of civilization and freedom. By transfiguring an ideological struggle into a moral one, such a revisionist treatment of American history provided an interpretative framework for reading the Cold War. The classic Western evidently worked as both genre and myth: a myth that helped justify ongoing inequality, discrimination and expansionism. The films reaffirmed a discourse of "American exceptionalism"-a belief going back to the writings of nineteenth-century political philosopher Alexis de Tocqueville-establishing the USA as an extraordinary nation bestowed with a "special spiritual and political destiny" (Hermann 4). This notion has pervaded the nation's history and functioned repeatedly as a key to understanding aspects of its cultural (Westerns, superheroes) and political life (expansionism, aggressive foreign policy). The state of exception makes entrenched conventions and legal boundaries appear non-applicable. In its role as the police/peacekeeper the USA has the ability to operate beyond the constraints tying down other nations.

9 American exceptionalism is closely entwined with frontier heroism. Accordingly, the Western frontier functions as a space where the moral laws and social norms are 
partially suspended: the hero ventures into the wild to complete his task, undergoes a transformation in this exceptional space and struggles to become re-integrated into the society (King 18). Scholars such as Young have demonstrated how the spatiotemporal representations of the frontier can be considered a "primal site of the US state's expression of power"; one through which the nations can "suspend their own constitutions and order to bring extralegal violence to bear against their enemies" (Young 28). However, this does not imply that the American West and the frontier it symbolizes are to be regarded as something fixed and monolithic. These concepts should much rather be considered mercurial and moldable; their boundaries blend into other regions of culture. The American West has in many ways always been something of a transnational space consisting of shifting and displaced frontiers (Campbell, The Rhizomatic West). Despite the defining role of the setting in the Western genre, Gonzalez argues that the mythical conceptions of the West do not refer to specific spaces, but to "a frontier in the Turnerian sense, the place where civilization and wilderness meet" (55). In a like vein, Campbell talks about the rhizomatic nature of the frontier, and sees it as something essentially deterritorialized. The Western is a concept transcending limitations such as time, space and genre, and should be understood as a wider mythological framework through which one can narrate a multitude of historical events (Campbell, The Rhizomatic West).

Lawrence and Jewett point out the parallels between frontier heroism and an archetypical narrative pattern they describe as the "American monomyth" (18). They have identified an endless cycle of stories centering on a community besieged by evil outsiders, in which an extraordinary hero has to venture forth and carry out a redemptive task. Traces of the American monomyth are not only to be found in narratives, but also appear in political discourse, especially in the aftermath of 9/11. Susan Kollin has undertaken an extensive investigation into how the Western has provided narratives in the past that proved useful in mediating national debates and anxieties. In her study on the role of frontier mythology in the post- 9/11 era, she discusses numerous examples of how the structures of the Western genre have functioned as a discursive weapon in the War on Terror. The concept of frontier heroism could work as both a mythic trope and a military doctrine. Soon after the 9/11 attacks, US president George W. Bush applied what Mann refers to as a "cowboy rhetoric" (159). Mann argues that the discourse Bush employed in his declaration of the War on Terror was infused with the language of the Wild West. Using one-liners seemingly straight out of a John Wayne film, the president warned the enemies that he would "smoke them out" and bring them in "dead or alive." These words reflect a conscious discursive strategy: the framing of the president's image-and of the nation's -in terms of cowboy masculinity deeply embedded in American culture. The US president takes on the persona of the Western sheriff: ready to saddle up, fill his holsters and bring evil to justice. This is a way to frame the War on Terror as, simultaneously, an act of international justice and another heavily mythologized chapter of American history.

\subsection{The Legacy of the Western}

11 Despite the deconstruction of the classical Western in the 1990s, it is evident that there exists a deep cultural nostalgia for the imagined past of the Wild West, allowing its mythology to survive in many different forms (Berg 244). The frontier as an actual 
historical referent has long disappeared, but this has not diminished the appeal of the mythology. On the contrary, as King believes, the mythology has been all the more free to expand through various media, including Hollywood films (18). I argue that American Sniper is one in a long line of conflict-focused narratives that employ frontier mythology as an interpretative framework through which America's aggressive foreign policy can be legitimized. Even though American Sniper is a war film, it concomitantly evokes the generic conventions, codes and themes of the classic Western-or rather the mythic heritage of the Western genre. While the war film has always been heavily tributary to the Western (Basinger), in American Sniper the former is used to mask the latter. While the parallels might not be apparent straight away, screenwriter Michael Hall admitted that it was his conscious decision to write the film as the story of a contemporary cowboy (Block), and main actor and producer Bradley Cooper took interest in such a take: "I loved the genre... I loved the concept of framing it as a Western." Hall furthers explains what to him the narrative arc of the story was: "The character goes from being a hero to being filled with vengeance and slipping over the dark side." This one-sentence synopsis perfectly summarizes the core of frontier heroism present in the story. In accordance with the Western genre, the film features the story of a man caught in the crossfire between wilderness and civilization, who has to claim an untamed space through acts of redemptive violence.

My argument is not so much that American Sniper is a neo-Western, but much rather that it contains certain Western codes and conventions, and that the integration of these generic conventions entails certain ideological complications. Grant has already pointed out that the Western mythology has survived in others genres (39). Elaborating on this, Carter makes the claim that frontier mythology has never really left American popular culture. The Western myth prevented its own demise by migrating to other Hollywood genres, such as the war, action and even the crime film. Therefore the underlying narrative patters and the structures of opposition of the Western genre remain very much alive (Carter 2). Saunders has argued that the Western has the "ability to digest and shape almost any source material" (6). Slotkin states that key to the endurance of Western myths is their adaptability across various social and historical contexts (Gunfighter Nation).

In various ways film genres are driven by myth. Altman has divided different academic approaches to genre-as-mythology into ritual and ideological ones, in which the genre film is seen as a collective cultural expression or an enforcement of the dominant ideology, respectively (23-24). Slotkin acknowledges the relevance of such an analysis since "within this structured marketplace of myths, the development of new genres or the substantial modification of existing ones can be read as a signal of active ideological concern" ("Gunfighters and Green Berets" 65). Altman considers the Western to be the most durable genre because it has "established the most coherent syntax." Genre provides the audience with a series of intertexts through which a new film can be interpreted and understood. As Altman rightfully points out, the interpretative contexts, helping to steer audience expectations and reactions, are ideological constructs; they provide and enforce a preferred reading (25). Along films such as Lonely Are the Brave (1962), Dirty Harry (1971), Desperado (1995) and No Country for Old Men (2007), American Sniper imports the components of the Western onto a different time and place. But perhaps the most fitting comparison to make is with the 1968 film The Green Berets. This Vietnam war movie starred and was co-directed by John Wayne, and 
was one of the few Vietnam war films to be released during the actual conflict. The film tried to apply a classic Western template onto the complicated geopolitical context of the Vietnam war; just as it had been the case with many 1950s films about the Second World War. However, as Slotkin has noted, the Vietnam war triggered a disruption and substantial revision of two of America's most prominent and durable genres to date: the combat film and the Western ("Gunfighters and Green Berets" 65). The subsequent clash between the heroic ideals of the frontier myth and the gruesome reality of the actual conflict was so brutal that the ideological framework previously supporting both genres caused a severe backlash. This resulted in the rejection of The Green Berets by critics and the general public for its simplistic portrayal of what was then already seen as a historical tragedy (Slotkin, "Gunfighters and Green Berets" 66).

14 With the dawn of the New Hollywood the Western mythos was getting out of date. Not only was the heroic frontier narrative no longer sustainable in cinema (let alone believable), but the moral pillars of the Western genre were violently assaulted by iconoclasts such as Sam Peckinpah, Arthur Penn, Robert Altman and Monte Hellman stateside, and figures such as Alejandro Jodorowsky and Sergio Leone in other countries. It is not that the Western genre was unpopular, far from it, one could even say that the genre had a revival in the early 1970s. Revisionist Westerns openly mocked the myths perpetuated since long in American culture and cinematically reiterated by authors such as Ford and Hawks. These new films featured cynical storylines, unlikable characters and raw depictions of violence. If there was anything like a frontier, it was blood-soaked and littered with bodies. Schatz calls such films "genre breakers" which subvert conventions to make a statement about the genre's faulty politics (38).

As Neale argues, one of the principal hallmarks of revisionist Westerns was a rejection of the imperialist mode inherent to America's "frontier mythology" and in its postwar "victory culture." In consequence, the Western underwent a decline in the 1980s and never truly recovered from the impact of counterculture (Neale 32). The cowboy had become an anachronism. What is wholly ironic is that Eastwood, too, was one of the celebrated authors who continued tearing down the mythical constructs of the genre. Not only is the actor's star persona tied with the aforementioned part of the genre's history (he starred in several of Leone's most iconic spaghetti Western and was the prototypical urban cowboy) (Cawelti 120), but he also directed a few brutal genrebreaking Westerns. High Plains Drifter (1973) is considered to be one of the most horrific genre-exercises of its time, The Outlaw Josey Wales (1976) was lauded for its strong native American characters, and Unforgiven (1992) provides a powerful meta-reflection on the Western mythology in relation to violence. Given Eastwood's reputation as one of the genre's most celebrated auteurs (Berg 215), it was no coincidence the 84-year-old director got hired to direct American Sniper. Main actor and producer Bradley Cooper admitted that he had wanted Eastwood for the project from the start, primarily because of his association with the Western genre: "When we pitched it initially [to Warner Bros.], I cited Unforgiven three or four times" (Block) .

16 I argue that American Sniper does the opposite of what the revisionist Western attempted and does so by employing-as was the case with The Green Berets-the Western mythos in representing a contemporary conflict. If we follow Cawelti's analogy of genre as tool-box (14), we should ask ourselves what purposes the different instruments that genres offers precisely serve. Using the case of American Sniper I demonstrate how the Western genre can work as a politically motivated analogy, 
showing the Iraq War as yet another chapter in the anthology of American heroics. Important here is Hodge's conception of genre in relation to metaphor: genre "provides a ready-made cultural framework to aid in both telling and interpreting the narrative" (Hodges 10). Not only does the Western as a convention seep into other established genres, but its generic codes can provide mythological/ideological frameworks. Evidently, these generic constructs can be utilized in favor of a number of political projects. Focusing on Western-inspired war films of the post-9/11 era, such as In the Valley of Elah (2007) and The Hurt Locker (2008), Kollin has noted that the period has also produced narratives delivering critical accounts of Wild West discourse and American exceptionalism. American Sniper, however, does not belong to the category of cinematic subversion, but much rather delivers a celebration of frontier heroism that justifies US expansionism and the violent practices it entails. By calling upon the mythic constructs of the Western genre American Sniper encourages its audience to frame the Iraq war in a specific manner, evoking a mythical past in which a savage space underwent a period of violence and disorganization before entering modernity. The Iraq war is here analogized with the Wild West, inducing the notion that America's involvement in Iraq is, too, a period in American history in which a savage, untamed space needs to be claimed and subjected to violent reform as to make way for civilization. The Middle East has therefore been transformed into the new American frontier.

\section{Deconstructing American Sniper}

\subsection{Generic Structures and Binary Oppositions}
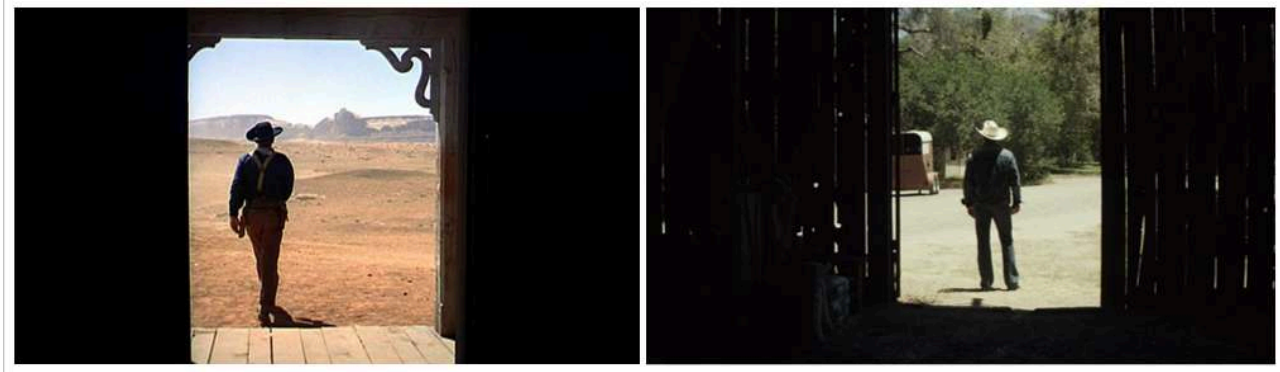

Rick Altman makes a distinction between themes and narrative structures, on the one hand, and iconography and more superficial conventions, on the other (225). Genres are defined through the interplay between these different levels, and this dynamic proves useful in analyzing how American Sniper evokes the generic spheres of the Western. American Sniper's Western mythology is most prominently displayed through the binary oppositions driving the narrative. However, there are also more superficial resemblances to be pointed out, as American Sniper wears its cowboy iconography blatantly on its sleeve. Kyle's childhood is told briefly through flashback and makes the most of this limited screentime by stressing a series of core American values. The love of guns, religion, the nuclear family and freedom all make an appearance in this romanticized slice of Americana set in Texas. Dipping tobacco and hunting deer are part of the all-American way of life and the Texas landscape does a job of recalling the vistas of Texas-set Westerns, such as The Alamo (1960) and Ford's iconic The Searchers (1956); Eastwood even recreates the iconic final shot of the latter film. 
of

of the American ideology: loyalty to one's family versus loyalty to one's country. Kyle is constantly torn between his duty to his comrades-as a soldier, and to his wife-as a providing husband. This is firmly established early on in the film when on Kyle's wedding day the news is announced that his SEAL-team will ship to Iraq. The film intercuts the slow wedding dance of Kyle and his bride with the loud machoism of his SEAL colleagues. His tuxedo is opened a bit to display a SEAL-badge under the wedding corsage, revealing what, literally and figuratively, lies closest to his heart. In this brief scene it's easy to recognize what Wollen has called the "problem of male heroism," an ode to bold entrepreneurs with a professional code he found in Hawks's Westerns (81). The "frontier" opened up by the conflict offers a realm of unparalleled excitement that clashes with the normality and mundaneness of the life at home. One soldier in the film, a victim of post-traumatic stress, compares war to an electric fence that sends "lightning through your bones... making it hard to hold on to anything else." According to King the binary opposite of adventure/action versus domesticity is not uncommon in action/war films: for example, The Hurt Locker showcases similar themes (140). Kyle feels out of step with his life at home. His inability to connect with his family and adapt to the life back at home can be seen as a central conflict deeply embedded in the genre. The portrayal of the soldier as both a gift and a burden to the society creates the ambiguities that the film tries to resolve: it is here that violence as a redemptive force plays a key part. 


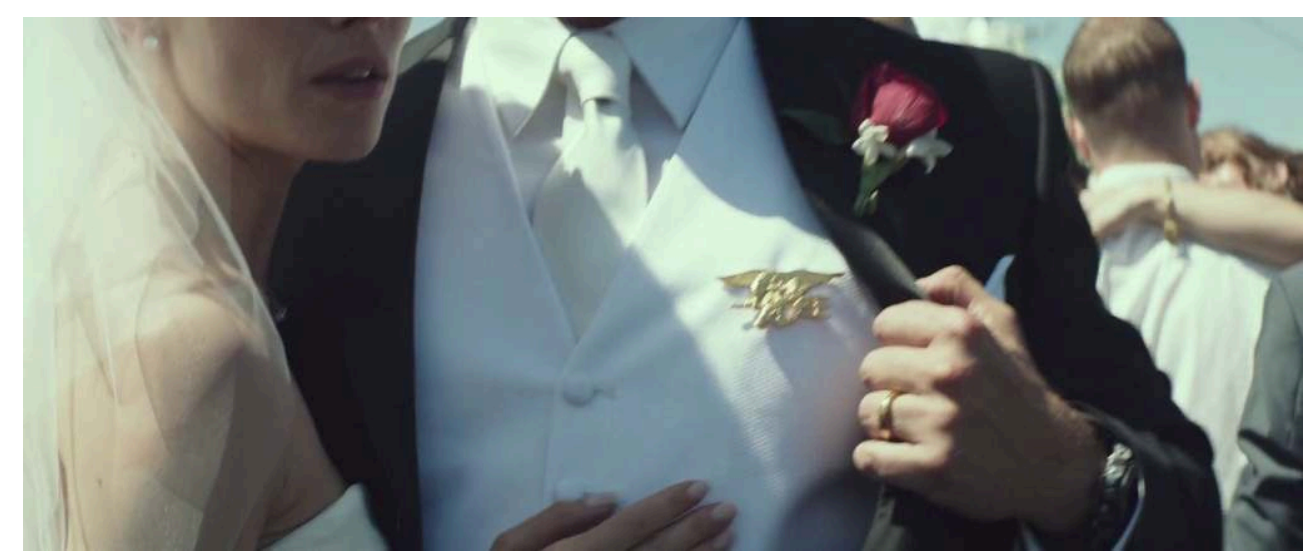

\subsection{Falluja: The New Frontier?} result of a threat from outside the society. Be it rival gunslingers, banditos or Native American wartribes, this outside force disrupts the stability of the community and can only be eliminated by the cowboy-hero. American Sniper adopts this element of Western syntax, but transfigures it to the 2003 Iraq invasion, metaphorazing America as the cowboy-hero, and the Muslim world as the outside threat. Kyle's role as a hero-savior is stressed at the beginning of the film through a flashback of Kyle's childhood. A small incident at the playground in which Kyle beats up a bully to protect his younger brother marks the beginning of the marine-to-be's savior complex, as his father elaborates on the difference between sheep, wolves and sheepdogs, and the importance to protect "someone who's being picked on." This incident can be read as a heavyhanded allegory for the exceptional role of the United States as a figurative protector of the world. They are the sheepdog, there to save the weak from the bullies on a global scale.

When Kyle grows up he experiences two moments of what can be best described as a "heroic awakening." The first is featured early on in the film, in 1998, after the United States embassy bombings in Nairobi, Kenya by the members of Egyptian Islamic Jihad (EIJ). The news broadcast stresses the horrific nature of the terrorist attack before listing the number of American casualties (that only 12 of the 213 casualties that day were American is a fact left unmentioned), the newscaster says that the bombing is part of "someone's war against the US... It's still unclear who our enemy is." Kyle picks up on this and states "Look at what they did to us." Who they precisely are, is a question the film answers implicitly later on. American Sniper frames the attacks of 1998 as the official dawn of a new threat against America, a threat that will fully reveal itself three years later. In the face of the new enemy, still lurking in the shadows, Kyle goes to enlist with the US Navy SEALS. The second incident that signifies heroic awakening happens a bit later in the film, when Kyle's fiancée urges him to come and watch the news. The event televised is the attack on the Twin Towers on 9/11. This event is framed in the exact same manner as the Nairobi attacks, and is followed shortly after by the first shots of Kyle's platoon in Iraq. The editing here implies a simple logic of cause and effect in geo-politics. The structuring of Kyle's life events in such a manner leads the audience to assume that there is an intrinsic link between 9/11 and the Iraq War. 

soldier says to Kyle upon his arrival: "Welcome to Fallujah: The new Wild West in the old Middle East." It is in this context that Kyle thrives as a Navy SEALS sniper, his unprecedented efficiency in killing rapidly granting him the status of a "legend" within the military. As Kyle racks up kills, his reputation of gunslinger-legend grows steadily, acquiring virtually mythical proportions. Soldiers start speculating about his number of confirmed kills, spread rumors of how fast he can shoot and a hero-cult is established around his persona. He is the guardian angel and savior of the troops. When out on house searches, he always leads the pack and is the first to enter uncharted territory. His status of legend among the soldiers is confirmed by the enemies who see him as a symbol of the invading forces. They call him Al-Shaitan Ramadi or "the Devil of Ramadi" and place a bounty on his head. The sum amounts to 21.000 dollars and later becomes 80.000 dollars, but apparently this amount was not impressive enough for the filmmakers who raises the bounty on Kyle's head to the fictional 180.000 dollars. This idea of placing bounties is another aspect that conforms to Western archetypes. The bounty for Al-Qaida operative Zarqawi, placed by the US government, amounted to $\$ 25 \mathrm{~m}$. In the military language, enemies are supposed to be brought back dead or captured, something further reminiscent of the old "dead or alive" mantra. According to Walker, historicizing plays an important role in the Western genre (12-13). Many stories are biopics about great men, and in these stories killing by numbers has often functioned as a form of symbolic capital. The sole reason why Kyle has been included is the dubious annals of history lies in not entirely different statistics. Kyle boasts the highest number of confirmed kills in the US military history-somewhere between 160 and 255.

The film's oppositions are further allegorized by Kyle's confrontation with rival sniper Mustafa, the main antagonist. Mustafa is a shooter legend similar to Kyle, only of Syrian origin and fighting on the enemy's side. Amongst his comrades, Mustafa, an Olympic medalist in sharpshooting, has acquired an equally legendary status, therefore he evidently represents Kyle's Other. Kyle always carries a bible, Mustafa a Koran. Kyle is a spitting image of hegemonic masculinity, boasting a muscular body, a big beard, a macho attitude, while Mustafa, on the other hand, has more effeminate characteristics: he has a slender body, long eyelashes, is cleanly shaven and more casually dressed. Whereas Kyle is a hulking bear of a soldier stomping the battleground with a considerable body mass, Mustafa jumps with a dancer-like athleticism from hideout to hideout. Most villains in the film are based on historical figures, but Mustafa is an entirely fictional creation. He's a concoction invented by the screenwriter to enhance the film's Western framework. The clash between these two men becomes the subject of a propaganda war, and the main narrative arc of the film. As Mustafa starts killing marines, some of them Kyle's squad mates, with increased frequency, Kyle becomes obsessively focused on him. The "duel" that ensues is both physical and symbolic. Mustafa does not utter a single line and his motivation remains unknown, which helps represent him as a "savage" threat. The manichean struggle between the West and the East, good and evil, is built up and resolved in a truly Western-like fashion. The two shooters keep missing each other until their final confrontation during a sandstorm, a true duel at sundown. Just as such a "last stand" provides the narrative with a necessary climax, this narrative trope also signifies an integral part of the frontier experience (King 138). When Kyle makes a record-breaking shot and eliminates Mustafa, he performs an act of redemptive violence that sets him free and saves the 
community. The killing of Mustafa can be considered an example of what Cawelti has dubbed "the epic moment" in American history; the precise instance when wilderness makes way for civilization (39).

Kyle does things that are unpopular, but necessary, and repeatedly clashes, in a true anti-hero fashion, with his superiors. They are presented as lazy bureaucrats, pitted powerlessly against the no-nonsense approach of Kyle. He confronts both the Arab enemy, barbaric but efficient, and the army machinery with its systematic rigor. While fighting for the latter, Kyle works best when he is given the chance to operate free from the restrictions of his superiors (i.e. not being bogged down by bureaucracy and petty rules). This is shown when Kyle leaves his sniping post against the will of the military command to join foot soldiers in the manhunt for Al-Qaida operatives. Despite violating the rules of military command, he ends up finding a military asset and saves the day, simply by taking matters into his own hands. We thus see that what makes Kyle such a skilled soldier and apt hero is the ability to step out of his role as a military grunt and go beyond the orders by trusting his intuition. His decisiveness and readiness to act is what makes him the needed extraordinary hero, while also juxtaposing his features with some core aspects of the American military. This could be taken further and even read as a continuation of the Western archetype of 'the man who knows Indians' (Slotkin, Gunfighter Nation 16). Kyle's extraordinary ability to beat "them" comes from his ability to think like "them." This can be seen in certain scenes where he proves to his superiors that he knows more about the enemy than they do (his superiors reprimand him for supposedly killing civilians, who then turn out to have been armed). The only problem is that Kyle ventures too far into the realm of savagery, and his suspension between civilization and wilderness takes a heavy toll on his life at home. It is this conflict that is presented as problematic, and not his killings. Kyle's ability to tap into his "savage" side is what makes him such a valuable asset to the community and what alienates him from it.

\subsection{Cowboys and Savages}

Within the first five minutes of the film Kyle is faced with the decision whether to shoot a woman and her child in cold blood, the act framed as a tragedy, but also nothing short of an imperative. A split-second before Kyle takes the shot, his life story is rewound to his childhood, subsequently building up to the moment of Kyle's kill. With the use of slow-motion and low-angle camera shots, the child and mother are identified as a threat. However, it's not a particular incident that haunts the film, but much rather the possibility of violent indulgence. The opening sequence functions as a spectacular introduction to the hardships of war and, at the same time, as anticipation of the many ethically questionable actions to come. American Sniper finds a way around the problematic nature of this one killing by never abandoning Kyle's perspective as soldier, clearly pointing out to the audience that the shots were a hard decision to make, but a right one. His action is further legitimized in a five-minute dialogue scene in which a fellow soldier reassures him by saying, "She could have taken out 10 marines." Two of them for ten of us: simple math. A conversation that ensues when Kyle expresses doubts about the "purity" of his kills offers the audience a moral justification. In analyzing the moral code of the Westerner, Robert Warshow defined the Westerner as possessing a scrupulosity in killing, which adds to the aura of justice surrounding him (qtd. in Berg 219). Berg points out that "the Westerner's just kill can 
be savored by audiences since any guilt by association has been absolved by the mechanics of the genre that have endorsed the hero's violence" (219). Using the shooting of a mother and her son as an opening scene, and then presenting flashbacks leading up to that event, American Sniper demands the audience's understanding. After we have repeatedly heard of the enemy's ruthlessness and become engaged with Kyle through an empathetic link, we see the events that were first portrayed as morally ambiguous are reinterpreted as righteous and necessary.

The Arab-threat presented in the film operates on various levels. On one level, it provides a textbook example of stereotypes, fears and codes associated with the Orientalist discourse. Ominous Muslim chants resound on the battlefield at night. Women are completely subjugated, nodding silently behind their burkas when the men speak. Most of all, savagery and barbarism are seen as inherent to the Arab character. By depicting a crowd of terrorists, thugs and insurgents from Iraq, Jordan, and Syria the film connects the whole of the Middle East to what emerges as an international terrorist network. This network is abstract rather than clearly defined, and does not refer so much to one specific organization (Al-Qaida is mentioned twice in the film), as to a larger intricate sphere of terrorism. Such opaqueness dissociates the enemy threat facing America from individuals, such as Zarqawi or Mustafa, or organizations, such as Al-Qaida, and makes it span the entire Middle Eastern world. This tendency toward abstraction is particularly problematic. The enemy has been reduced to a conceptual danger: savagery incarnate. Sam Keen has pointed out how our vision of "the enemy" derives its potency from abstraction (Faces). American Sniper further enforces such an impression by visualizing its Arab characters either from concealing camera angels or in masses. After Kyle's squad has successfully completed a raid, a crowd of citizens marches angrily forward like a wave of animosity.

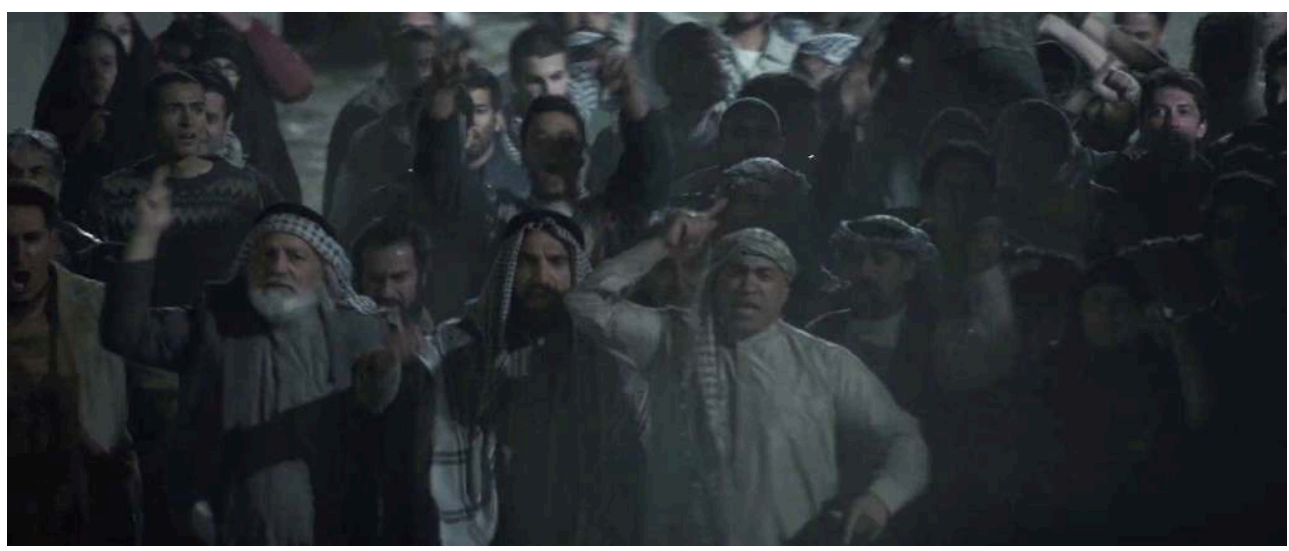

The Western analogy here ensures that the enemy becomes more of a symbolic threat driving the narrative than a group of isolated antagonists. This is further sustained by American Sniper's deliberate lack of depth or characterization. Like the Indian, the new villain embodies a violent primitive. Such a categorization conforms to Buscombe's typology of the "Indian as unknown Other," threatening the onward march of the EuroAmerican civilization (156). The lawless Falluja is a setting not unlike a frontier settlement terrorized by bandits and thugs. Most inhabitants have fled the town, those who have stayed live in fear of the barbaric "Butcher": an Al-Qaida enforcer who uses primitive weaponry such as power drills and cleavers to mangle and dismember his enemies. As genre traditions chiefly determine how a film's hero and villain get portrayed (Vanhala 109), it is easy to notice that American Sniper calls upon generic 
codes of villainy to present its antagonist. The Butcher is clad in black, reminiscent of the "blackhat" villain in films such as Red River (1948). The enemy savage is a force that cannot be reasoned with or understood. "That's evil like I've never seen before," laments Kyle after killing the woman and her son. Xenophobic prejudices are quite explicit in the film. The soldiers repeatedly refer to Iraqi citizens as "savages," and reiterate that what they are dealing with is "pure evil." In the moments of narrative exposition the enemy is repeatedly vilified so as to discourage the viewer from empathizing with the gunned down Arabs. The military chief in command assures Kyle that there are no longer innocent civilians in the city after the evacuation, "Any middle age male is here to kill you."

This vilification does not stop at middle-aged males, but also includes women and children in the vastness of the Muslim threat. The opening scene is almost recreated midway through the film as a child picks up an RPG, ready to fire at an American convoy. Innocent-looking women are informants who alert the insurgents when the American troops approach. Every single Arab character in the film is depicted in a negative way: at best as a coward, and at worst as a demonized sadist killer. The one Iraqi citizen who cooperates with American soldiers is a greedy opportunist who demands large sums of money for his services. He and his son are then brutally killed by the Butcher. Such a scenario reaffirms the view of the Orient as something that has to be protected from itself (Said). Even seemingly innocent civilians are eventually "unmasked" as terrorist mules. When holding a stakeout in a family house, the host invites the soldiers for dinner. The family's hospitality looks like a rare moment of warmth in the film, until Kyle discovers what can best be described as a terrorist treasure chest under the floor. The father has stashed guns, grenades, ammunition and other kinds of explosives. The air of paranoia is sustained throughout the film by the use of sniper POV shots. The tension evoked by such moments results from creating both a moral and literal blindspot for the audience. Since the view from Kyle's sniper scope is limited, danger can be hidden just out of frame. Furthermore, as established in multiple scenes of military exposition, every civilian can be an insurgent in disguise (Pötzsch).

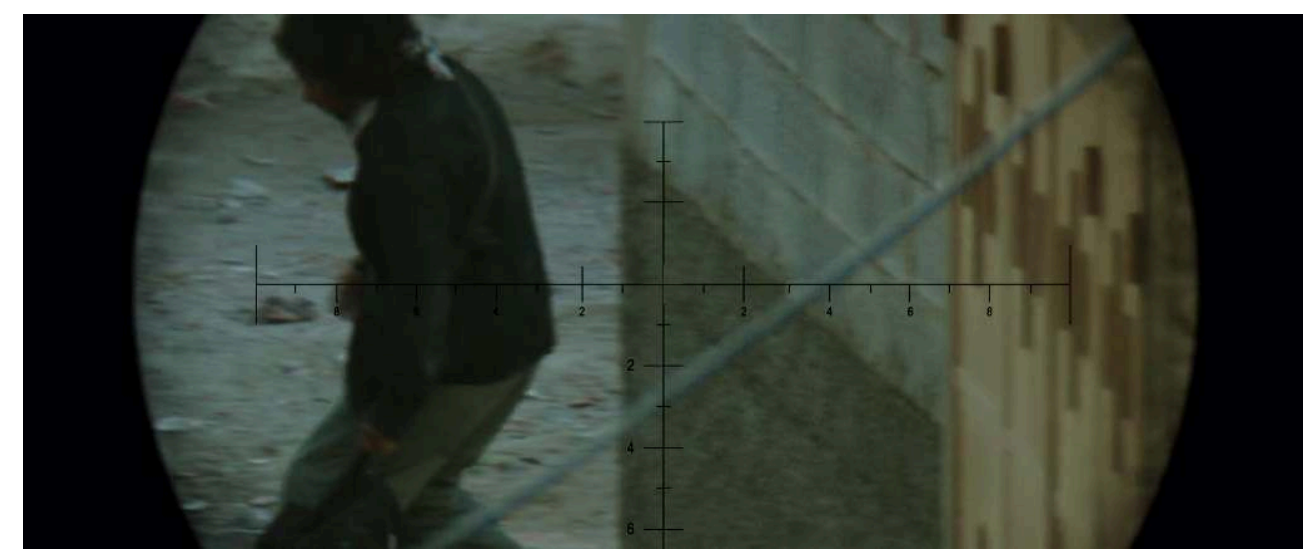

30 As the film restructures and reorganizes the "frontier", the American conflict and the use of military violence can be better understood, if not entirely condoned. In its evocation of frontier mythology the film delivers to audiences a powerful frame of reference through which contemporary geopolitics are to be read, at the same time promoting an aggressive foreign policy and a militaristic disregard for human life. Such 
attitudes are further enforced by American Sniper's representation of the enemy as a savage entity that can only be eliminated through acts of regenerative violence. This discursive framing of violence could be considered crucial to the shaping of what Judith Butler has referred to as "(non-)grievable life." Butler writes that "the differential distribution of grievability across populations has implications for why and when we feel politically consequential affective dispositions such as horror, guilt, righteous sadism, loss and indifference" (24-25). Such sentiments thereby facilitate the justification of war as a viable, and indeed necessary, means of political action. At the same time American Sniper enforces a mythology in which violence is celebrated and soldiers are seen as heroes. When Kyle is killed at the end by a traumatized war vet, he emerges as a martyr. The credits roll on and when the score by Ennio Morricone plays over the archival footage of Kyle's funeral, it's clear his death is to be seen as the equivalent of the cowboy riding slowly towards the sunset for the last time.

\section{Conclusion}

In the words of André Bazin, "The Western was born out of an encounter between a mythology and a means of expression" (41). This article has shown how genre can be used as a political frame through which contemporary geopolitics can be interpreted. In American Sniper genre operates as a medium that evokes a mythological framework: by way of generic conventions and narrative structures associated with the classic Western, the film offers a preferred reading of the military actions of Kyle and the US, in context of the Iraq war, as an extension of frontier heroism. The manner in which American Sniper utilizes the Western's generic conventions demonstrates what Carter has described as "the cultural-ideological influence that the myth of the West still holds over the political trajectory of the United States in its self-assumed role of figurative policeman" (12). By analogizing this conflict with the mythic struggle of civilization/ wilderness, the Iraq invasion is depicted not only as a pre-emptive course of action, but also as a natural and necessary war to fight. This mythic recuperation of the 2003 Iraq invasion as part of a "just" war is partially enabled through a belief in the righteous and redemptive force of violence. The enemies in American Sniper embody an abstract evil, a homogenous savage other devoid of reason and mercy, rather than a specific nation or faction.

In many ways the film is in itself a mythologization of the life and times of Chris Kyle. American Sniper's creative team found a successful way to soften the edges of Kyle's autobiography and glorify a man who referred to the Iraqis as savages, repeatedly voiced his regrets about not killing more of them (West), and whose existence was defined by his extraordinary ability to kill. It is a narrative that is, at its heart, a propagandist fable, yet American Sniper succeeds in making a blatant political narrative seem "natural" (Barthes). Contrary to Hall's claims that the story is an a-political account of one man, American Sniper does far more than focalize the Iraq war through the experiences of one US Navy Seals sniper. Eastwood injects Western ideology and mythology into the narrative, ultimately restructuring American historical imaginings. It's ironic that the director who tore down the mythological varnish of the Hollywood Western in his earlier films, has now reapplied this very varnish in American Sniper. The sun will not likely set on the old West any time soon. 


\section{BIBLIOGRAPHY}

Altman, Rick. Film/Genre. London: British Film Institute, 1998. Print.

Barthes, Roland. Mythologies. Trans. Annette Lavers. New York: Hill and Wang, 1972. Print.

Basinger, Jeanine. The World War II Combat Film: Anatomy of a Genre. New York: Columbia University Press, 1986. Print.

Bazin, André. What Is Cinema? Trans. Hugh Gray. Berkeley, Los Angeles, London: University of California Press, 1972. Print.

Berg, Chuck. "Fade Out in the West: The Western's Last Stand?" Film Genre 2000. Ed. Wheeler W. Dixon. Albany: State University of New York Press, 2000. 211-223. Print.

Block, Alex B. “The Making of 'American Sniper': How an Unlikely Friendship Kickstarted the Clint Eastwood Film.” Hollywoodreporter. Web. 15 Sep 2016.

http://www.hollywoodreporter.com/news/making-american-sniper-how-an-760963

Braudy, Leo. "Genre: The Conventions of Connection." Film Theory and Criticism: Introductory Readings. Ed. Leo Braudy and Marshall Cohen. Oxford and New York: Oxford University Press, 2004. Print. 535-552. Print.

Burgoyne, Robert. Film Nation: Hollywood Looks at US History. Minneapolis: University of Minnesota Press, 1997. Print.

Buscombe, Edward. The BFI Companion to the Western. New York: Atheneum, 1988. Print.

Butler, Judith P. Frames of War: When Is Life Grievable. London: Verso Books, 2009. Print.

Campbell, Neil. Post-Westerns. London and Lincoln: University of Nebraska Press, 2013. Print.

---. The Rhizomatic West: Representing the American West in a Transnational, Global, Media Age. London and Lincoln: University of Nebraska Press, 2008. Print.

Carter, Matthew. Myth of the Western: New Perspectives on Hollywood's Frontier Narrative. Edinburgh: Edinburgh University Press, 2014. Print.

Cawelti, John G. Adventure, Mystery, and Romance: Formula Stories as Art and Popular Culture. Chicago: University of Chicago Press, 1977. Print.

---. The Six-Gun Mystique Sequel. Bowling Green: Bowling Green State University Popular Press, 1999. Print.

Dockterman, Eliana. “Clint Eastwood Says American Sniper Is Anti-War.” Time. Web. 15 Sep 2016. http://time.com/3747428/clint-eastwood-american-sniper-anti-war/

González, Jesús Ángel. “New Frontiers for Post-Western Cinema: Frozen River, Sin Nombre, Winter's Bone." Western American Literature 50.1 (2015): 51-76. Print.

Grant, Barry K. Film Genre: From Iconography to Ideology. London: Wallflower Press, 2007. Print. Hermann, Margaret. “The Study of American Foreign Policy." Routledge Handbook of American Foreign Policy. Ed. Steven W. Hook and Christopher M. Jones. London and New York: Routledge, 2012. 3-18. Print.

Hodges, Adam. The "War on Terror" Narrative: Discourse and Intertextuality in the Construction and Contestation of Sociopolitical Reality. Oxford and New York: Oxford University Press, 2011. Print. 
Jewett, Robert. and Shelton J. Lawrence. The American Monomyth. New York: Anchor Press, 1977. Print.

Kain, Erik. ““American Sniper' Isn’t Pro-War Propaganda.” Forbes. Web. 15 Sep 2016.

http://www.forbes.com/sites/erikkain/2015/01/29/american-sniper-isnt-pro-war-propaganda/ $\# 18 \mathrm{c} 8507841 \mathrm{e} 0$

Keen, Sam. Faces of the Enemy: Reflections of the Hostile Imagination. New York: Harper \& Row, 1986. Print.

King, Geoff. Spectacular Narratives: Hollywood in the Age of the Blockbuster. London: IB Tauris, 2000. Print.

Kollin, Susan. Captivating Westerns: The Middle East in the American West. London and Lincoln: University of Nebraska Press, 2015. Print.

Lusted, David. The Western. London: Pearson Education, 2003. Print.

Mann, Bonnie. Sovereign Masculinity: Gender Lessons from the War on Terror. Oxford and New York: Oxford University Press, 2013. Print.

Mexal, Stephen J. "Two Ways to Yuma: Locke, Liberalism and Western Masculinity in 3:10 to Yuma." The Philosophy of the Western. Ed. Jennifer L. McMahon and Steve Csaki. University Press of Kentucky, 2010. 69-87. Print.

Neale, Stephen. Genre and Hollywood. Hove: Psychology Press, 2000. Print.

Nichols, Bill. Movies and Methods: An Anthology. Vol. 1. Berkeley, Los Angeles, London: University of California Press, 1985. Print.

Potzsch, Holger. "Ubiquitous Absence: Character Engagement in the Contemporary War Film." Nordicom Review: Nordic Research on Media and Communication 34.1 (2013): 125-145. Print.

Rose, Deborah Bird, and Richard Harding Davis. Dislocating the Frontier: Essaying the Mystique of the Outback. Canberra: ANU E Press, 2005. Print.

Said, Edward W. Orientalism. New York: Vintage, 1979. Print.

Saunders, John. The Western Genre: From Lordsburg to Big Whiskey. London: Wallflower Press, 2001. Print.

Schatz, Thomas. Hollywood Genres: Formulas, Filmmaking, and the Studio System. New York: McGrawHill, 1981. Print.

Slotkin, Richard. Regeneration Through Violence: The Mythology of the American Frontier, 1600-1860. Middletown: Wesleyan University Press, 1973. Print.

---. "Gunfighters and Green Berets: The Magnificent Seven and the Myth of Counter-Insurgency." Radical History Review 44 (1989): 65-90. Print.

---. Gunfighter Nation: The Myth of the Frontier in Twentieth-Century America. Norman: University of Oklahoma Press, 1992.

Taibi, Mati. “'American Sniper’ Is Almost Too Dumb to Criticize.” RollingStone. Web. 20 Sep 2016.

http://www.rollingstone.com/politics/news/american-sniper-is-almost-too-dumb-tocriticize-20150121

Vanhala, Helena. The Depiction of Terrorists in Blockbuster Hollywood Films, 1980-2001: An Analytical Study. Jefferson, NC: McFarland, 2011. Print. 
Walker, Janet. "Captive Images in the Traumatic Western: The Searchers, Pursued, Once Upon a Time in the West, and Lone Star." Westerns: Films Through History. Ed. Janet Walker. New York and London: Routledge, 2001. 219-251. Print.

West, Lindy. "The Real American Sniper Was a Hate-Filled Killer. Why Are Simplistic Patriots Treating Him as a Hero?" The Guardian. Web. 30 Aug 2016.

http://www.theguardian.com/commentisfree/2015/jan/06/real-american-sniper-hate-filledkiller-why-patriots-calling-hero-chris-kyle

Wollen, Peter. Signs and Meaning in the Cinema. Indianapolis: Indiana University Press, 1972. Print. Woold, Nick. “American Sniper: Anti-Muslim Threats Skyrocket in Wake of Film's Release.” The Guardian. Web. 30 Aug 2016.

http://www.theguardian.com/film/2015/jan/24/american-sniper-anti-muslim-threatsskyrocket

Young, Alex Trimble. "Settler Sovereignty and the Rhizomatic West, or, the Significance of the Frontier in Postwestern Studies.” Western American Literature 48.1 (2013): 115-140. Print.

\section{ABSTRACTS}

Clint Eastwood's war film American Sniper (2014), based on the autobiography of (in)famous Navy Seals sniper Chris Kyle, was met on release with considerable commercial success and political controversy. This article investigates how through adopting generic structures and binary oppositions of the classic Western film American Sniper succeeds in evoking a sense of "frontier mythology." By generically restructuring historical events, American Sniper analogizes the Iraq War with the mythic struggle of civilization/wilderness and portrays Kyle as a trailblazing frontiersman leading the way to Western expansion. Such a mythical conception of the Western genre operates as a political frame through which a jingoist discourse on the Iraq war is reaffirmed and within which audiences can interpret the conflict-and the undertaken military measures-as necessary and just.

\section{INDEX}

Keywords: American Sniper, genre, Iraq War, mythology, Westerns, Othering, frontier 